\title{
High cortisol and cortisone levels are associated with breast milk dioxin concentrations in Vietnamese women
}

\author{
Teruhiko Kido', Tung Van Dao², Manh Dung Ho', Nhu Duc Dang ${ }^{3}$, Ngoc Thien Pham², \\ Rie Okamoto', Tai The Pham ${ }^{4}$, Shoko Maruzeni ${ }^{4}$, Muneko Nishijo4, \\ Hidewaki Nakagawa4, Seijiro Honma ${ }^{1,5}$, Son Ke Le ${ }^{6}$ and Hung Ngoc Nguyen ${ }^{3}$ \\ ${ }^{1}$ School of Health Sciences, College of Medical, Pharmaceutical and Health Sciences, Kanazawa University, 5-11-80 \\ Kodatsuno, Kanazawa, Ishikawa, Japan, ${ }^{2}$ Department of Biochemistry and ${ }^{3}$ Division for Mitigation of the \\ Consequences of the Chemicals Used During the War on Human Health (10-80 Division), Hanoi Medical University, \\ Hanoi, Vietnam, ${ }^{4}$ Department of Epidemiology and Public Health, Kanazawa Medical University, Ishikawa, Japan, \\ ${ }^{5}$ ASKA Pharma Medical Co. Ltd., Kawasaki, Japan and ${ }^{6}$ Environment Administration, Ministry of Natural Resources \\ and Environment, Hanoi, Vietnam
}

\author{
Correspondence \\ should be addressed \\ to T Kido \\ Email \\ kido@mhs.mp \\ kanazawa-u.ac.jp
}

\begin{abstract}
Objective: Dioxin (polychlorinated dibenzodioxins + polychlorinated dibenzofurans) is one of the most toxic chemical substances known. Although it is suspected to cause endocrine disruption, very few epidemiological studies have been carried out on its effects on human steroid hormones. The aim of this study was to elucidate the association of dioxin exposure with steroid hormone levels in the saliva and serum of Vietnamese women.

Study design: Two areas, namely Phu Cat (hot spot) and Kim Bang (nonexposed area), were selected for the study. The study subjects consisted of 51 and 58 women respectively. Saliva, blood, and breast milk samples were collected from the subjects in both the areas.

Methods: Cortisol, cortisone, DHEA, androstenedione, estrone, and estradiol levels in serum and saliva were determined by liquid chromatography-tandem mass spectrometry; dioxin concentrations in breast milk were measured by gas chromatography-mass spectrometry.

Results: Dioxin concentrations in the breast milk of women from the dioxin hot spot were three to four times higher than those in the breast milk of women from the nonexposed area. Good correlations were found between the levels of six steroid hormones in saliva and those in serum respectively. Salivary and serum cortisol and cortisone levels in women from the dioxin hot spot were significantly higher than those in women from the nonexposed area $(P<0.001)$ and those in all the subjects were positively associated with dioxin concentrations in Vietnamese women $(P<0.01)$.

Conclusion: These results suggest that dioxin influences steroidogenesis in humans. Saliva samples can be used for hormone analysis and are therefore excellent specimens in epidemiological studies.
\end{abstract}

\section{Introduction}

Dioxin is one of the most toxic chemical substances known and is a persistent environmental contaminant. During the Vietnam War (1961-1971), the USA Air Force sprayed over 80 million liters of chemical herbicides on southern battlefields for general defoliation and crop destruction (1). This chemical herbicide was contaminated with highly toxic 2,3,7,8-tetrachlorodibenzo-p-dioxin (dioxin-TCDD) (1). Kreuzer et al. (2) have estimated that the half-life of dioxin in human adults is $7-11$ years. Although the war in Vietnam ended more than 40 years (c) 2014 European Society of Endocrinology Printed in Great Britain
Published by Bioscientifica Ltd. 
ago, dioxin hot spots are still found in and around three former USA airbases $(3,4,5)$. TCDD accumulates in the fatty tissues of the body as a result of the lipophilic nature of dioxin $(6,7)$. As such, studies on dioxin concentrations in lactating mothers are mainly carried out using breast milk. Dioxin concentrations in the breast milk of women in the sprayed areas in Vietnam are still higher than those in the breast milk of women in the nonexposed areas (8).

Some of the adverse effects associated with dioxin exposure may be considerably mediated by alterations in endocrine function $(9,10,11,12)$. There have been a few scientific studies concerning the effect of dioxin exposure on human sex steroid hormones in Seveso residents and chemical industry workers $(13,14)$. Recently, in an epidemiological study, we have demonstrated that salivary cortisol, cortisone, estradiol $\left(\mathrm{E}_{2}\right)$, and androstenedione (A-dione) levels in primiparae are related to dioxin concentrations in their breast milk $(15,16,17)$.

The aim of this study was to further elucidate the relationship between dioxin exposure and steroid hormone levels in the serum and saliva of Vietnamese mothers by using a larger number of subjects residing in a dioxin hot spot and a nonexposed area. Another aim was to compare salivary steroid hormone levels with serum steroid hormone levels determined by liquid chromatography-tandem mass spectrometry (LC-MS/MS) analysis.

\section{Subjects and methods}

\section{Study area}

Agent Orange/dioxin hot spot $\boldsymbol{~ T h e ~ d i o x i n ~ h o t ~ s p o t ~}$ selected was Phu Cat Air Base, where chemical herbicides had been stored and the aircraft used to spray Agent Orange/Dioxin during the Vietnam War had been washed. This site is located in Phu Cat district, Binh Dinh province, and is one of the three dioxin hot spots in South Vietnam. The study subjects were chosen from the population that had been living in and around Phu Cat Air Base after the war. Records show that 17000 drums of Agent Orange, 9000 drums of Agent White, and 2900 drums of Agent Blue had been stored there (18).

Control area $>$ The nonexposed area selected was Kim Bang district, Ha Nam province, in the north of Vietnam, which was not exposed to chemical defoliants during the war and is a rural area that has not been affected by industrial pollution.

\section{Subjects and methods}

The study subjects consisted of 51 lactating women from the dioxin hot spot and 58 from the nonexposed area. All the mothers were aged between 20 and 30 years with children aged between 13 and 16 months at the time of the study. A sample of breast milk was collected from the lactating women in September 2008, and serum and saliva samples were collected from the same subjects 1 year later (August). All the blood, breast milk, and salivary samples were collected in the morning (between 0800 and $1000 \mathrm{~h}$ ). The temperature in both the areas was around $30-34{ }^{\circ} \mathrm{C}$ at the time of the study. After local government officials and medical staff had explained the purpose of the study to 109 lactating females (51 from the dioxin hot spot and 58 from the nonexposed area), all agreed to participate in the study. A sample of about $20 \mathrm{ml}$ of breast milk was collected from all the participants. Saliva samples $(2-3 \mathrm{ml})$ were selfcollected with support from medical staff. After 5 min of rinsing the mouth with water, saliva was collected directly into a $15 \mathrm{ml}$ bakelite test tube. Medical staff used a $10 \mathrm{ml}$ syringe to extract about $10 \mathrm{ml}$ of venous blood from lactating women, and serum was separated from this blood sample by centrifugation $(6500 \boldsymbol{g} \times 10 \mathrm{~min})$. Saliva and serum samples that were collected were stored in chemically cleaned cooling containers and frozen in dry ice over several days. All the samples were then transported to Japan and were stored at $-70^{\circ} \mathrm{C}$ until analysis.

The mothers were asked to provide information concerning their family, age, family income, and residence period. The BMI of the lactating mothers was determined and compared between the two areas. The Medical Ethics Committee of Kanazawa University approved this study (Permission number: Health 89).

\section{Reagents}

Cortisol, cortisone, DHEA, A-dione, estrone, and $\mathrm{E}_{2}$ were obtained from Sigma-Aldrich. Estrone- ${ }^{13} \mathrm{C}_{4}, \mathrm{E}_{2^{-}}{ }^{13} \mathrm{C}_{4}$, and progesterone- ${ }^{13} \mathrm{C}_{3}$ were purchased from Hayashi Chemical Co. Ltd. (Osaka, Japan). Cortisol- ${ }^{2} \mathrm{H}_{4}$ was obtained from $\mathrm{C} / \mathrm{D} / \mathrm{N}$ Isotopes (Pointe-Claire, Canada), and DHEA- ${ }^{2} \mathrm{H}_{4}$ was obtained from Aska Pharma Medical Co. Ltd. (Kawasaki, Japan). ${ }^{13} \mathrm{C}_{12}-1,2,3,4-\mathrm{TCDD}$ and ${ }^{13} \mathrm{C}_{12}-1,2,7,8$ TCDF were obtained from Wellington Laboratories (Guelph, Ontario, Canada). Picolinic acid, 2-methyl6-nitrobenzoic acid anhydride, 4-dimethylaminopyridine, pentafluorobenzyl bromide, and 2-fluoro-1-methylpyridinium $p$-toluenesulfonate were purchased from Tokyo Chemical Industry Co. Ltd. (Tokyo, Japan). Triethylamine 
was obtained from Wako Pure Chemical Industries Ltd. (Osaka, Japan). Oasis MAX (60 mg, 3 ml), Bond Elut C18, and InterCept pharm cartridges were purchased from Waters Co. (Milford, MA, USA), Varian (Palo Alto, CA, USA), and GL Science (Tokyo, Japan) respectively.

Reagent A contained picolinic acid (40 mg), 2-methyl6-nitrobenzoic acid anhydride (40 mg), and dimethylaminopyridine $(20 \mathrm{mg}) / \mathrm{ml}$ of tetrahydrofuran. Reagent B contained 2\% 2-fluoro-1-methylpyridinium p-toluenesulfonate/ml of dichloromethane.

\section{Instruments}

The LC-MS/MS system used was as follows: an API 5000 triple-stage quadrupole mass spectrometer (Applied Biosystems, Inc.) connected to an LC-20AD pump and SIL HTC autosampler (Shimadzu, Kyoto, Japan). An electrospray ionization (ESI) ion source device was employed for the analysis of estrone and $\mathrm{E}_{2}$. The column used was Xterra-C-18 (Waters Co.).

An API 4000 triple-stage quadrupole mass spectrometer (Applied Biosystems, MDS Sciex, Toronto, ON, Canada) with an ESI ion source, an Agilent 1100 HPLC system (Agilent Technologies, Waldbronn, Germany), and a PTC pal autosampler (CTC Analytics, Zwingen, Switzerland) were employed for the analysis of neutral steroids. The column used was Cadenza CD-C18 $(250 \times 3 \mathrm{~mm}$, with an internal diameter of $3 \mu \mathrm{m}$; Imtakt, Kyoto, Japan).

The gas chromatography-mass spectrometry (GC-MS) system used was as follows: a high-resolution mass spectrometer (HRMS; JEOL MStation-JMS700) equipped with a GC (HP-6980, Hewlett-Packard, Palo Alto, CA, USA). The column used was ENV-5MS with $30 \mathrm{~m} \times 0.25 \mathrm{~mm}$ ID of $0.25 \mu \mathrm{m}$ film thickness (Kanto Chemical Co., Inc., Tokyo, Japan).

\section{Analysis of serum steroids by LC-MS/MS}

The procedure used for the analysis of serum steroids was a modified method of Yamashita et al. (19). Human serum $(200 \mu \mathrm{l})$ was mixed with purified water to a volume of $1.0 \mathrm{ml}$ and then mixed with $1 \mathrm{ng}$ cortisol- ${ }^{2} \mathrm{H}_{4}$, $100 \mathrm{pg}$ DHEA- ${ }^{2} \mathrm{H}_{4}, 100 \mathrm{pg}$ progesterone- ${ }^{13} \mathrm{C}_{3}, 100 \mathrm{pg}$ estrone- ${ }^{13} \mathrm{C}_{4}$, and $100 \mathrm{pg} / 100 \mu \mathrm{l} \mathrm{E} \mathrm{E}^{-}{ }^{13} \mathrm{C}_{4}$ as an internal standard (IS). The samples were extracted with $3 \mathrm{ml}$ ethyl acetate, and the extract was applied onto a Bond Elut C18 cartridge to remove impurities. After the elution of steroid fractions with $80 \%$ acetonitrile solution, the residue was allowed to react with reagent $A(19,20)$. The reaction mixture was then applied onto an InterSept pharm cartridge to remove excess reagents. A part of residue containing picolinoyl derivatives and nonderivative steroids was directly assayed by LC-MS/MS as described by Yamashita et al. (19).

The estimation ions were as follows: cortisol and cortisol- ${ }^{2} \mathrm{H}_{4}, 468.2 / 309.2$ and 472.2/454.3; cortisone and cortisol- ${ }^{2} \mathrm{H}_{4}, 468.2 / 309.2$ and 472.2/454.3; DHEA and DHEA- ${ }^{2} \mathrm{H}_{4}, 394.3 / 175.1$ and 398.1/179.4; A-dione and progesterone- ${ }^{13} \mathrm{C}_{3}, 287.4 / 109.0$ and $318.3 / 100.1$; estrone and estrone- ${ }^{13} \mathrm{C}_{4}, 376.1 / 156.9$ and 380/160.8; and $\mathrm{E}_{2}$ and $\mathrm{E}_{2}{ }^{-13} \mathrm{C}_{4}, 483.3 / 264.0$ and $487.2 / 268.2$. The lowest analytical limits for cortisol, cortisone, DHEA, A-dione, estrone, and $\mathrm{E}_{2}$ were $50,50,5,10,1.0$, and $0.5 \mathrm{pg} / \mathrm{assay}$ respectively. Both the accuracy and precision were within $\pm 20 \%$ of the lowest level in intra- and inter-day assays and both were within $\pm 15 \%$ for concentrations other than the lowest concentration.

\section{Analysis of salivary steroids by LC-MS/MS}

Human saliva (1.0-1.5 ml) was mixed with the IS used in the analysis of serum steroids. The extracts were then applied onto a Bond Elut C18 cartridge to separate the polar steroid fractions (cortisol and cortisone) with $20 \%$ acetonitrile solution $(2 \mathrm{ml})$ and nonpolar steroid fractions with $80 \%$ acetonitrile solution $(3 \mathrm{ml})$. The nonpolar fraction was applied onto an ion cartridge column prewashed with methanol $(3 \mathrm{ml}), 0.1 \mathrm{M} \mathrm{NaOH}(1 \mathrm{ml})$, and water $(3 \mathrm{ml})$ successively. The nonpolar fraction was separated into a neutral fraction with methanol and an estrogen fraction (estrone and $\mathrm{E}_{2}$ ) with $1 \%$ formic acidmethanol. The organic phase for both the fractions was evaporated to dryness. After derivation of the estrogen fraction with $2 \%$ pentafluorobenzyl bromide-acetonitrile $(100 \mu \mathrm{l})$ and $5 \% \mathrm{KOH}$-ethanol solution $(50 \mu \mathrm{l})$ at $53^{\circ} \mathrm{C}$, the derivatives obtained were further separated into the estrone and $\mathrm{E}_{2}$ derivatives on an Intersept SI cartridge column using 15-50\% ethyl acetate-hexane. The estrone3-pentafluorobenzyl fraction was converted into the estrone-3-pentafluorobenzyl-17-hydrazino-2-methylpyridinium derivative by the method of Higashi (21), whereas the $E_{2}$-3-pentafluorobenzyl fraction was converted into $\mathrm{E}_{2}$-3-pentafluorobenzyl-17-O-2-pyridinium ether using reagent $B$ (22). Both the derivatives were purified on a Bond Elut C18 cartridge column to remove excess reagents, and the purified estrogen derivatives were mixed with $100 \mu \mathrm{l}$ of $1 \%$ formic acid/methanol/acetonitrile (20:1:1), and a $20 \mu \mathrm{l}$ aliquot of this solution was used for LC-MS/MS. The neutral fraction was treated according to the picolinic acid method described above for 
serum samples. The fraction obtained was estimated by LC-MS/MS (API 5000). The estimation of steroid hormone was performed by using selected reaction monitoring (SRM) and the transitions used are as follows: cortisol and cortisol- ${ }^{2} \mathrm{H}_{4}, 363.3 / 121.2$ and 367.3/121.2; cortisone and cortisol- ${ }^{2} \mathrm{H}_{4}, 361.2 / 162.8$ and 367.3/121.2; DHEA and DHEA- ${ }^{2} \mathrm{H}_{4}, 394.3 / 175.1$ and 398.1/179.4; A-dione and progesterone- ${ }^{13} \mathrm{C}_{3}, 287.4 / 109.0$ and $318.3 / 100.1$; estrone and estrone- ${ }^{13} \mathrm{C}_{4}, 556.3 / 313.1$ and 560.3/379.3; $\mathrm{E}_{2}$ and $\mathrm{E}_{2^{-}}{ }^{13} \mathrm{C}_{4}, 544.2 / 339.0$ and 548.2/343.2.

The lowest analytical limits for cortisol, cortisone, DHEA, A-dione, estrone, and $\mathrm{E}_{2}$ were 50, 50, 2, 10, 0.5, and $0.1 \mathrm{pg} /$ assay respectively. Both the accuracy and precision were within $\pm 20 \%$ of the lowest level in intra- and interday assays and both were within $\pm 15 \%$ for concentrations other than the lowest concentration.

\section{GC-MS analysis of dioxin in breast milk}

Breast milk samples were analyzed following a previously reported method $(8,23)$. After the extraction of fat from $10 \mathrm{~g}$ of breast milk, $40-80 \mathrm{pg}$ of $17-{ }^{13} \mathrm{C}_{12}$-labeled polychlorinated dibenzodioxin (PCDD)/polychlorinated dibenzofuran (PCDF) congeners were added as an IS.

A series of purification steps involving alkali digestion and chromatography on a multi-layer silica gel column and an active carbon-dispersed silica gel column were carried out to separate and collect the PCDDs/PCDFs. The final sample extract was evaporated to dryness under a nitrogen steam and then re-dissolved by addition of $20 \mu \mathrm{l}$ of nonane containing $40 \mathrm{pg}$ of ${ }^{13} \mathrm{C}_{12}-1,2,3,4-\mathrm{TCDD}$ and ${ }^{13} \mathrm{C}_{12}-1,2,7,8$-TCDF as external standards. Finally, determination was done using a gas chromatograph equipped with a HRMS.

The analysis of dioxin was carried out in the selected ion monitoring mode at a resolution of 10000 , and values that were obtained were converted to toxic equivalents (TEQs) using the World Health Organization toxicity equivalency factors $(7,24)$.

Quality control and quality assurance were ensured following the guidelines described in the Japanese Industrial Standard (JIS). Eligibilities for the analysis of dioxin were certified using the natural reference powder milk CRM607 provided by the European Commission. The recovery rate was typically in the range of $60-95 \%$, and the detection limits were determined at a signalto-noise ratio of $3(\mathrm{~S} / \mathrm{N}=3)$ on a lipid basis. Values for congener concentrations below the detection limits were set to half the detection limits.
Table 1 Characteristics of lactating mothers in the dioxin hot spot and nonexposed area. Data are reported as means \pm s.D.s for a normal distribution and as medians (interquartile ranges) for a non-normal distribution.

\begin{tabular}{|c|c|c|c|}
\hline & $\begin{array}{c}\text { Dioxin hot spot } \\
(n=51)\end{array}$ & $\begin{array}{l}\text { Nonexposed } \\
\text { area }(n=58)\end{array}$ & $\begin{array}{c}P \\
\text { value }\end{array}$ \\
\hline Age (years) & $27.3 \pm 3.68$ & $26.1 \pm 2.82$ & $0.063^{a}$ \\
\hline Weight (kg) & $48.5 \pm 6.63$ & $48.8 \pm 5.04$ & $0.786^{a}$ \\
\hline Height $(\mathrm{cm})$ & $152.3 \pm 5.47$ & $152.7 \pm 5.10$ & $0.721^{a}$ \\
\hline BMI $\left(\mathrm{kg} / \mathrm{m}^{2}\right)$ & $20.9 \pm 2.22$ & $20.9 \pm 1.90$ & $0.866^{a}$ \\
\hline $\begin{array}{l}\text { Residence } \\
\text { period (years) }\end{array}$ & $21.0(21.0-26.0)$ & $22.5(18.8-25.0)$ & $0.803^{b}$ \\
\hline $\begin{array}{l}\text { Family income } \\
\qquad\left(\times 10^{4} \mathrm{VND} / \mathrm{month}\right)\end{array}$ & $200(100-300)$ & $200(110-300)$ & $0.924^{b}$ \\
\hline
\end{tabular}

VND, Vietnamese dong

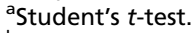

b'Wilcoxon's signed-rank test.

\section{Statistical analyses}

Data are presented as means \pm s.D.s in the case of a normal distribution and as medians (interquartile ranges) for a non-normal distribution, as determined using the Shapiro-Wilk test. Pearson's correlation coefficients were calculated. Statistical comparisons of the mean differences between the two areas were made using Student's $t$-test in the case of a normal distribution or the Wilcoxon's signedrank test for a non-normal distribution. The significance level was set at $P<0.05$. All the statistical analyses were carried out using the SPSS 12.0 Software, JMP@9 Software package (SAS Institute, Cary, NC, USA), and Microsoft Excel 2010.

\section{Results}

\section{Comparison of characteristics of the study subjects from the dioxin hot spot and nonexposed area}

Table 1 summarizes the characteristics, such as age, weight, height, and BMI, of lactating women from the two study areas $(n=109)$. The characteristics did not differ significantly between the two areas. Likewise, family income and residence period were similar in both the areas.

\section{Comparison of hormone levels in mothers from the dioxin hot spot and nonexposed area}

Table 2 summarizes the salivary levels of six steroid hormones (cortisol, cortisone, DHEA, A-dione, estrone, and $\left.\mathrm{E}_{2}\right)$ for all the study subjects $(n=109)$ from the dioxin 
Table 2 Steroid hormone levels in the saliva of lactating mothers in the dioxin hot spot and nonexposed area. Data are reported as medians (interquartile ranges).

\begin{tabular}{lcc}
\hline & & Dioxin hot spot $(n=51)$ \\
\cline { 1 - 1 } Cortisol $(\mathrm{ng} / \mathrm{ml})$ & & $1.89(1.30-3.16)$ \\
Cortisone $(\mathrm{ng} / \mathrm{ml})$ & & $10.8(8.41-13.7)$ \\
DHEA $(\mathrm{pg} / \mathrm{ml})$ & & $154.7(105.8-232.3)$ \\
A-dione $(\mathrm{pg} / \mathrm{ml})$ & & $56.6(42.5-75.6)$ \\
Estrone $(\mathrm{pg} / \mathrm{ml})$ & & $1.20(0.58-2.10)$ \\
Estradiol $(\mathrm{pg} / \mathrm{ml})$ & & $0.22(0.13-0.46)$ \\
\hline
\end{tabular}

\begin{tabular}{c}
\hline Nonexposed area $(n=58)$ \\
\hline $1.10(0.70-1.90)$ \\
$7.74(5.46-10.6)$ \\
$133.8(104.1-189.6)$ \\
$55.5(45.8-74.6)$ \\
$0.84(0.62-1.47)$ \\
$0.18(0.10-0.33)$ \\
\hline
\end{tabular}

\begin{tabular}{l}
\hline P value \\
\hline $0.0001^{\mathrm{a}}$ \\
$0.0001^{\mathrm{a}}$ \\
$0.223^{\mathrm{a}}$ \\
$0.923^{\mathrm{a}}$ \\
$0.146^{\mathrm{a}}$ \\
$0.27^{\mathrm{a}}$ \\
\hline
\end{tabular}

${ }^{a}$ Wilcoxon's signed-rank test.

hot spot and nonexposed area, as determined by LC-MS/MS analysis. Salivary cortisol and cortisone levels were significantly higher in women from the dioxin hot spot than in those from the nonexposed area $(P<0.001)$. There were no significant differences between the two areas for any of the other salivary hormones.

Table 3 summarizes the serum levels of the six steroid hormones in the study subjects from the two areas. Cortisol and cortisone levels were significantly higher in women from the dioxin hot spot than in those from the nonexposed area $(P<0.001$ and $P<0.01$ respectively). There were no significant differences in serum DHEA, A-dione, estrone, and $\mathrm{E}_{2}$ levels.

\section{Comparison of TEQ of dioxin levels in the breast milk of lactating women from the dioxin hot spot and nonexposed area}

The median total TEQ of PCDDs (6.29 pg/g lipid), PCDFs (4.44 pg/g lipid), and total PCDDs + PCDFs (11.04 pg/g lipid) for women in the dioxin hot spot $(n=51)$ was significantly higher than for those in the nonexposed area (PCDDs, $1.87 \mathrm{pg} / \mathrm{g}$ lipid; PCDFs, $1.41 \mathrm{pg} / \mathrm{g}$ lipid; and total PCDDs + PCDFs, $3.15 \mathrm{pg} / \mathrm{g}$ lipid). Specifically, dioxin concentrations in the breast milk of lactating women from the dioxin hot spot were more than three times higher than those in the breast milk of lactating women from the nonexposed area $(P<0.001)$.

\section{Correlation between steroid hormone levels in saliva or serum and dioxin concentrations in breast milk}

Figure 1 shows the correlations between cortisol and cortisone levels in saliva and dioxin concentrations in the breast milk of study subjects from both the dioxin hot spot and nonexposed area. Significantly positive correlations were found between salivary cortisol and cortisone and breast milk dioxin levels (total PCDDs + PCDFs; $P<0.001$ ).

Figure 2 shows the correlations between cortisol and cortisone levels in serum and dioxin concentrations (total PCDDs + PCDFs $)$ in breast milk $(P<0.01$ and $P<0.001)$; these correlations were also found to be significant.

\section{Correlation between salivary steroid hormones and serum steroid hormones}

We analyzed six kinds of steroid hormones in saliva and serum by LC-MS/MS. Figure 3 shows a significantly positive correlation between cortisol, cortisone, DHEA, estrone, A-dione, and $\mathrm{E}_{2}$ in the serum and those in the saliva of study subjects from both the dioxin hot spot and nonexposed area respectively $(P<0.001)$.

\section{Discussion}

The region investigated in the present study (Phu Cat) is one of the three major dioxin hot spots in Vietnam.

Table 3 Hormone levels in the serum of lactating mothers in the dioxin hot spot and nonexposed area. Data are reported as medians (interquartile ranges).

\begin{tabular}{|c|c|c|c|}
\hline & Dioxin hot spot $(n=51)$ & Nonexposed area $(n=58)$ & $P$ value \\
\hline Cortisol (ng/ml) & $94.2(71.9-141.6)$ & $66.3(52.2-103.8)$ & $0.0001^{a}$ \\
\hline Cortisone (ng/ml) & $26.7(22.1-30.8)$ & $22.0(17.2-27.6)$ & $0.003^{a}$ \\
\hline DHEA (pg/ml) & 4566 (3158-6493) & 4446 (3319-6617) & $0.753^{a}$ \\
\hline A-dione $(\mathrm{pg} / \mathrm{ml})$ & $1484(1098-2070)$ & $1650(1259-2172)$ & $0.155^{a}$ \\
\hline Estrone $(\mathrm{pg} / \mathrm{ml})$ & $23.7(13.8-38.3)$ & $26.2(19.0-45.3)$ & $0.176^{a}$ \\
\hline Estradiol (pg/ml) & $21.3(11.2-37.0)$ & $21.9(11.9-39.5)$ & $0.888^{a}$ \\
\hline
\end{tabular}

aWilcoxon's signed-rank test. 

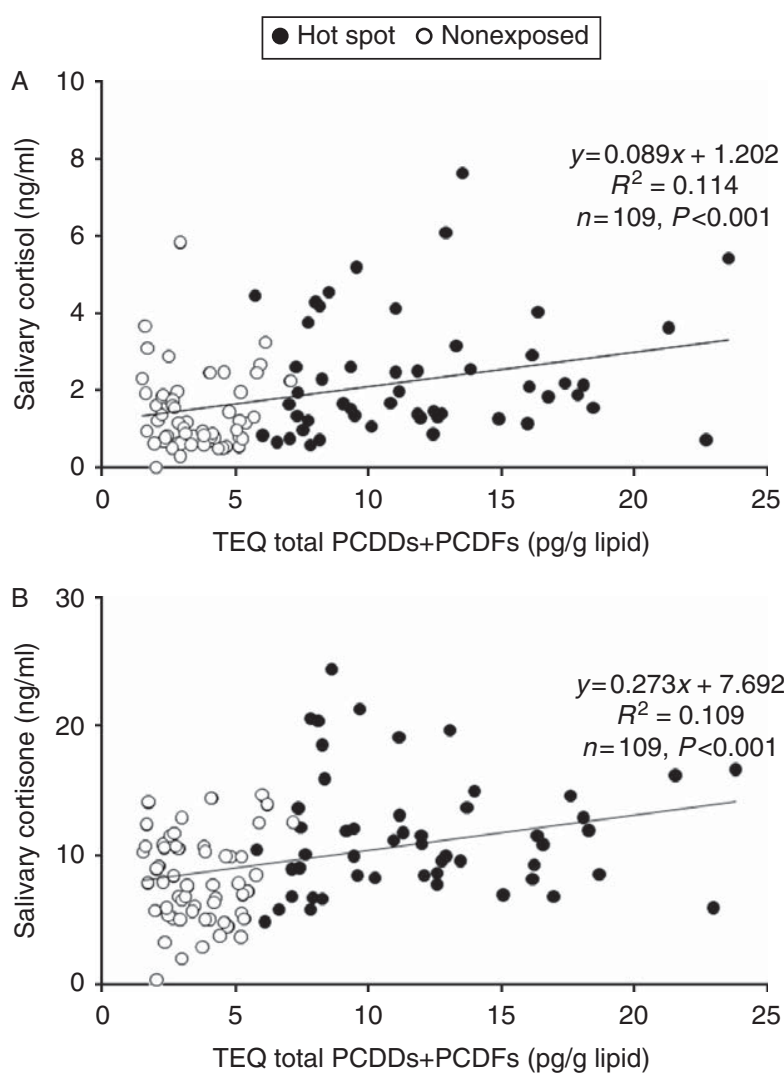

Figure 1

Correlation between cortisol (A) and cortisone (B) levels in saliva and dioxin concentrations in breast milk of women from the dioxin hot spot and nonexposed area.

Indeed, according to Dwernychuk $(3,25)$, the concentration of TCDD recorded at Phu Cat is $194 \mathrm{pg} / \mathrm{g}$ in sediments, and the Hatfield Consultancy (26) has reported that the maximum TCDD level of $236000 \mathrm{pg} / \mathrm{g}$ TCDD in soil taken from the vicinity of Phu Cat is much higher than the internationally recognized standard of $1000 \mathrm{pg} / \mathrm{g}$ TCDD in soil.

In this study, we demonstrated that dioxin concentrations in breast milk were three- to fivefold higher in women from the dioxin hot spot than in those from the nonexposed area, despite the fact that more than 40 years have passed since the war. This result is consistent with that of our previous study (15). A similar study carried out in Seveso has estimated that TCDD concentrations in females are fivefold higher in an exposed area than in a control area after 30 years (27). These studies suggest that the dioxin burden in humans continues for a long duration after environmental exposure.
Salivary cortisol and cortisone levels were found to be significantly higher in women from the dioxin hot spot than in those from the nonexposed area $(P<0.001)$. Furthermore, serum cortisol and cortisone levels were also significantly higher in women from the dioxin hot spot $(P<0.001$ and $P<0.01$ respectively). We have recently carried out a similar study on salivary steroid hormone levels in primiparae in a dioxin hot spot $(15,16,17)$. In the present study on lactating women (first, second, or third child), which included a larger number of subjects $(n=109)$, significantly higher serum and salivary cortisol and cortisone levels were found in lactating women from the dioxin hot spot (Tables 2 and 3; $P<0.001$ ).

The relationship between dioxin and hormone levels is linear in the dioxin concentration range of $2-25 \mathrm{pg} / \mathrm{g}$ lipid (Figs 1 and 2; $P<0.01$ ). The adrenal gland is a major accumulation site for lipophilic dioxins and Poly chlorinated biphenyls (PCBs) in the body. Three types of

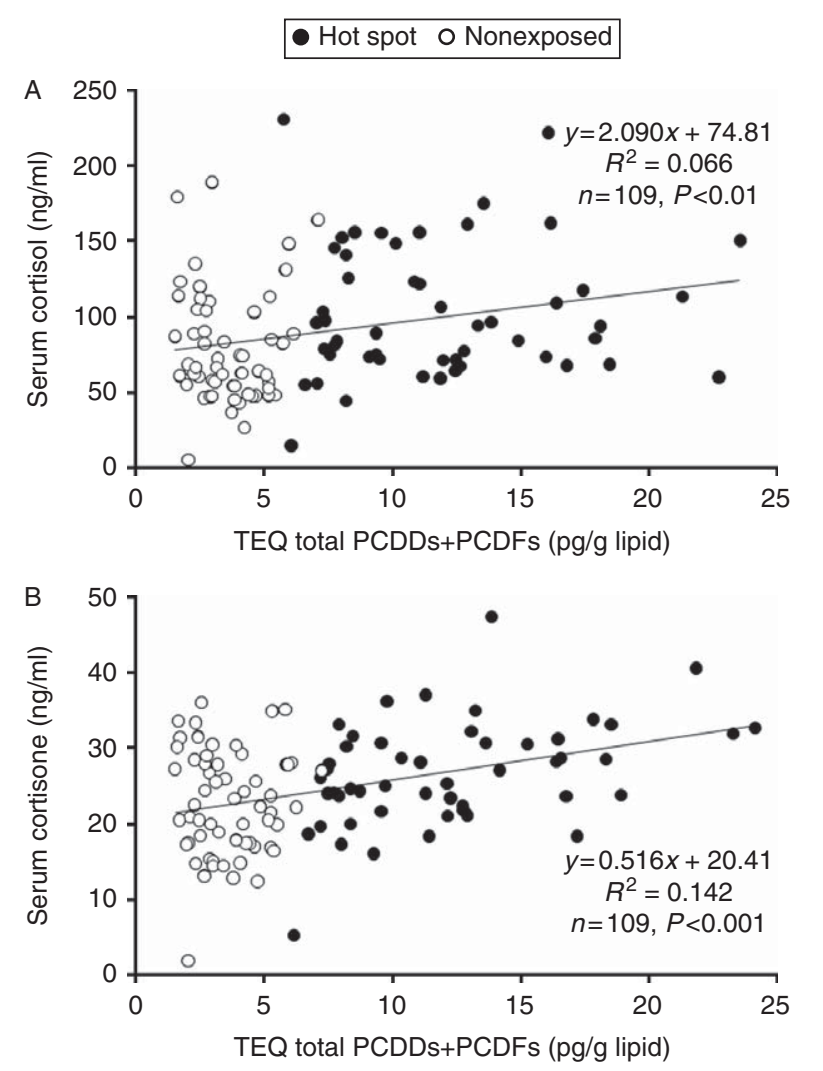

Figure 2

Correlation between cortisol (A) and cortisone (B) levels in serum and dioxin concentrations in breast milk of women from the dioxin hot spot and nonexposed area. 

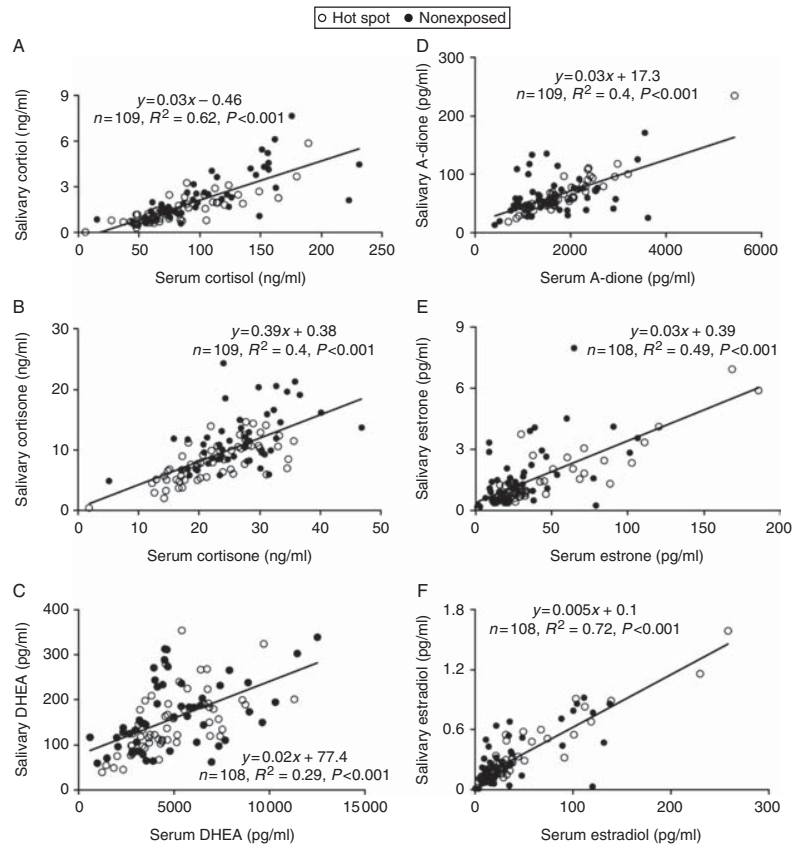

\section{Figure 3}

Correlation between serum and salivary hormone levels in women from the dioxin hot spot and nonexposed area.

(A) Cortisol, (B) cortisone, (C) DHEA, (D) A-dione, (E) estrone, and $(F)$ estradiol.

steroid hormones (cortisol, aldosterone, and DHEA) are synthesized in the adrenal gland, and their levels, and therefore ratios, are regulated by adrenocorticotrophin. In this study, cortisol and cortisone levels in both serum and saliva were found to be significantly higher in women from the dioxin hot spot than in those from the nonexposed area, whereas the DHEA levels varied less between women from the two areas. These results clarified one of the aims of the present study. We supposed that women who had abnormal steroid hormone levels would have a higher risk of adrenocortical dysfunction such as hyperglycemia, suppression of immune system, and inhibition of osteoblast function.

In our previous study on 18 primiparae in a dioxin hot spot, in which increased salivary cortisol and cortisone levels were observed, an inverted U-shape was obtained for the TEQ of dioxin levels (15). In the present study carried out in 109 lactating mothers, increased cortisol and cortisone levels were found in serum and saliva. However, the model between steroid hormone and dioxin levels could be fit by a straight line rather than with a nonlinear inverted U-shaped curve. The difference between the findings of the present study and those of the previous study carried out in primiparae may be due to the inclusion of lactating mothers who had given birth to their first, second, or third child in the present study.

The levels of the other hormones studied in this study (DHEA, A-dione, estrone, and $\mathrm{E}_{2}$ ) did not change significantly between the dioxin hot spot and nonexposed area. Our previous study had shown that the mean salivary $\mathrm{E}_{2}$ or A-dione levels did not differ significantly between the dioxin hot spot and nonexposed area, although the curve between salivary $\mathrm{E}_{2}$ or A-dione levels and dioxin levels was U-shaped in primiparae (16). In the Seveso study, men aged 22-31 years had reduced concentrations of sperm and serum $\mathrm{E}_{2}$, but increased concentrations of folliclestimulating hormone (FSH), 22 years after exposure. By contrast, men aged 32-39 years had increased total sperm and serum FSH concentrations and reduced $\mathrm{E}_{2}$ concentrations, compared with those from the control area. Serum testosterone levels did not vary (13). These results suggest that exposure at certain time periods of life may affect the subsequent impact of the exposure. Steroid hormones in serum are categorised into three types: the free type (1-3\%), the bioavailable type (30-40\%), and the inactive type (50\%). A correlation between salivary cortisol and serum free cortisol concentrations has been reported (28). Salivary steroid hormones are known to be excreted in serum in a free form. The total serum cortisol:cortisone ratio is $\sim 3: 1$, whereas the salivary cortisol:cortisone ratio is $\sim 1: 6$. There are two main reasons for this marked difference in the cortisol:cortisone ratio between serum and saliva. First, salivary gland

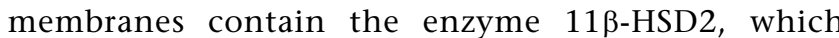
irreversibly converts cortisol into cortisone as it passes through this membrane. Second, more than 90\% of the circulating hormone in human serum is bound to proteins such as corticoid-binding globulin (CBG) and albumin. Cortisone binds to CBG in serum with a tenfold lower affinity than cortisol. Consequently, the proportion of free cortisone in serum is much higher than that of cortisol. These findings are reflected in the salivary steroid levels. We also determined the ratios of free to proteinbound hormones from salivary and serum hormone levels. The ratio of each salivary:serum hormone concentration was significantly higher in women from the dioxin hot spot than in those from the nonexposed area, except that for DHEA (data not shown). These higher ratios may be related to any one of the numerous effects of dioxin exposure on endocrine disruption. In other words, dioxin may have an effect on steroid-binding proteins and may influence the natural balance of hormone circulation. 
It should be noted that low doses of dioxin also affect immune function (29). Thus, in the study that examined the effects of TCDD on Vietnam War air force veterans, Pavuk et al. (30) found an increase in TSH levels, but no change in tri-iodothyronine $\left(\mathrm{T}_{3}\right)$ or free $\mathrm{T}_{3}$ levels. However, results of the studies on endocrine disruption by chemicals can be difficult to interpret and are readily misinterpreted, thus meaning that the same factor could stimulate or inhibit (31).

We found a strongly positive correlation between salivary hormones and serum hormones $(P<0.001$; see Fig. 3). We chose saliva as the matrix for steroid hormone analysis in this study as it is noninvasive and easy to collect from subjects, even from children, and is feasible for use in epidemiological studies.

LC-MS/MS is an excellent technique with higher sensitivity and accuracy than standard immunoassay methods. Furthermore, this technique can also be used to simultaneously analyze six steroids, including those, such as cortisol and cortisone, with a similar molecular structure using only $0.1 \mathrm{ml}$ of serum. We also established an analytical method for $\mathrm{E}_{2}$ involving chemical derivatization that allows even trace amounts to be detected. This method has a limit of quantification of $0.1 \mathrm{pg} / \mathrm{ml}$ by LC-MS/MS.

There are some limitations to this study. The study subjects were women $(n=109)$ who had given birth up to 1 year before the study and therefore may have returned to a normal menstrual cycle with the physiological activity inherent to normal hormone regulation (32). Therefore, it is probably difficult to determine the levels of sex hormones, such as progesterone and estrogen, in women with varying menstrual cycles.

In summary, the relationship between dioxin exposure and endocrine disruption requires further clarification to be able to evaluate adverse human health effects caused by dioxin and/or other environmental chemicals. It is especially important to continuously monitor the health of mothers throughout life and to investigate any possible influence on the development of their children at dioxin hot spots in Vietnam.

\section{Declaration of interest}

The authors declare that there is no conflict of interest that could be perceived as prejudicing the impartiality of the research reported.

\section{Funding}

This study was supported by grants from the Japan Society for the Promotion of Science (grant-in-aid for scientific research (A) number 19209021 and (C) number 23590735)

\section{Acknowledgements}

The authors thank the medical staff at Kim Bang and Phu Cat medical center for their assistance. They also thank all the women who participated in the study. They thank the officers of the 10-80 Division, Hanoi Medical University, Vietnam, for making this study possible.

\section{References}

1 Stellman JM, Stellman SD, Christian R, Weber T \& Tomasallo C. The extent and patterns of usage of Agent Orange and other herbicides in Vietnam. Nature 2003422 681-687. (doi:10.1210/jcem-34-6-1102)

2 Kreuzer PE, Csanady GA, Baur C, Kessler W, Papke O, Greim H \& Filser JG. 2, 3,7,8-Tetrachlorodibenzo-p-dioxin (TCDD) and congeners in infants. A toxicokinetic model of human lifetime body burden by TCDD with special emphasis on its uptake by nutrition. Archives of Toxicology 199771 383-400. (doi:10.1210/er.19.6.717)

3 Dwernychuk LW. Dioxin hot spots in Vietnam. Chemosphere 200560 998-999. (doi:10.1210/er.2005-0006)

4 Schecter A, Dai LD, Papke O, Prange J, Constable JD, Matsuda M, Thao VD $\&$ Piskac AL. Recent dioxin contamination from Agent Orange in residents of a southern Vietnam city. Journal of Occupational and Environmental Medicine 200143 435-443. (doi:10.1210/jcem-25-11-1470)

5 Mai TA, Doan TV, Tarradellas J, de Alencastro LF \& Grandjean D. Dioxin contamination in soils of southern Vietnam. Chemosphere $2007 \mathbf{6 7}$ 1802-1807. (doi:10.1016/j.chemosphere.2006.05.086)

6 Fingerhut MA, Sweeney MH, Patterson DG, Piacitelli LA, Morris JA, Marlow DA, Hornung RW, Cameron LW, Connally LB, Needham LL et al. Levels of 2,3,7,8-tetrachlorodibenzo-p-dioxin in the serum of US chemical workers exposed to dioxin contaminated products: interim results. Chemosphere 198919 835-840. (doi:10.1210/jc.2007-1322)

7 Van den Berg M, Birnbaum L, Denison M, De Vito M, Farland W, Feeley M, Fiedler H, Hakansson H, Hanberg A, Haws L et al. The (2005) World Health Organization re-evaluation of human and mammalian toxic equivalency factors for dioxins and dioxin-like compounds. Toxicological Sciences 200693 223-241. (doi:10.1210/en.2003-0646)

8 Pham TT, Nishijo M, Kido T, Nakagawa H, Maruzeni S, Naganuma R, Anh NT, Morikawa Y, Luong HV, Anh TH et al. Dioxin concentrations in breast milk of Vietnamese nursing mothers: a survey four decades after the herbicide spraying. Environmental Science \& Technology 201145 6625-6632. (doi:10.1023/A:1009970909015)

9 Bestervelt LL, Pitt JA, Nolan CJ, Cai Y, Piper DW, Dybowski JA, Dayharsh GA \& Piper WN. In vitro 2,3,7,8-tetrachlorodibenzo- $p$-dioxin interference with the anterior pituitary hormone adrenocorticortropin. Toxicological Sciences 199844 107-115. (doi:10.1210/jc.2004-0424)

10 Peterson RE, Theobald HM \& Kimmel GL. Developmental and reproductive toxicity of dioxins and related compounds: cross-species comparisons. Critical Reviews in Toxicology 199323 283-335. (doi:10.1210/jc.86.7.3143)

11 Bookstaff RC, Moore RW \& Peterson RE. 2,3,7,8-Tetrachlorodibenzo$p$-dioxin increases the potency of androgens and estrogens as feedback inhibitors of luteinizing hormone secretion in male rats. Toxicology and Applied Pharmacology 1990104 212-224. (doi:10.1210/jc.2003-030410)

12 Diamanti-Kandarakis E, Bourguignon J-P, Giudice LC \& Hauser R. Endocrine-disrupting chemicals: an endocrine society scientific statement. Endocrine Reviews 200930 293-342. (doi:10.1210/jc.86.2.551)

13 Mocarelli P, Gerthoux PM, Patterson DG, Milani S, Limonta G, Bertona M, Signorini S, Tramacere P, Colombo L, Crespi C et al. Dioxin exposure, from infancy through puberty, produces endocrine disruption and affects human semen quality. Environmental Health Perspectives 2008116 70-77. (doi:10.1007/s00198-008-0591-5)

14 Egeland GM, Sweeney MH, Fingerhut MA, Wille KK, Schnorr TM \& Halperin WE. Total serum testosterone and gonadotropins in workers exposed to dioxin. American Journal of Epidemiology 1994139 272-281. (doi:10.1210/endo-123-3-1476) 
15 Nhu DD, Kido T, Naganuma R, Suzuki H, Kuroda N, Honma S, Tai PT, Maruzeni S, Nishijo M, Nakagawa $\mathrm{H}$ et al. Salivary cortisol and cortisone levels, and breast milk dioxin concentrations in Vietnamese primiparas. Toxicological and Environmental Chemistry 201092 1939-1952. (doi:10.1210/jcem-68-3-535)

16 Nhu DD, Kido T, Hung NN, Thom LT, Naganuma R, Son LK, Honma S, Maruzeni S, Nishijo M \& Nakagawa H. Dioxin levels in the breast milk and estradiol and androgen levels in the saliva of Vietnamese primiparae. Toxicological and Environmental Chemistry 201193 824-838. (doi:10.1080/02772248.2010.484247)

17 Manh HD, Kido T, Okamoto R, XianLiang S, Hoang N, Nakano M, Tai PT, Maruzeni S, Nishijo M, Nakagawa $\mathrm{H}$ et al. The relationship between dioxins and salivary steroid hormones in Vietnamese primiparae. Environmental Health and Preventive Medicine 201318 221-229. (doi:10.1007/s12199-012-0310-x)

18 Young AL. The history, use, disposition and environmental fate of Agent Orange. Environmental Science and Pollution Research 201017 1016-1019. (doi:10.2307/2531110)

19 Yamashita K, Miyashiro Y, Maekubo H, Okuyama M, Honma S, Takahashi M \& Numazawa M. Development of highly sensitive quantification method for testosterone and dihydrotestosterone in human serum and prostate tissue by liquid chromatography-electrospray ionization tandem mass spectrometry. Steroids $2009 \mathbf{7 4}$ 920-926. (doi:10.1046/j.1365-2265.2001.01275.x)

20 Yamashita K, Okuyama M, Watanabe Y, Honma S, Kobayashi S \& Numazawa M. Highly sensitive determination estrone and estradiol in human serum by liquid chromatography-electrospray ionization tandem mass spectrometry. Steroids 200772 819-827. (doi:10.1016/ j.steroids.2007.07.003)

21 Higashi T. Salivary hormone measurement using LC/MS/MS: specific and patient-friendly tool for assessment of endocrine function. Biological \& Pharmaceutical Bulletin 201235 1401-1408. (doi:10.1210/jc.86.6.2459)

22 Arai S, Miyashiro Y, Shibata Y, Kashiwagi B, Tomaru Y, Kobayashi M, Watanabe Y, Honma S \& Suzuki K. New quantification method for estradiol in the prostatic tissues of benign prostatic hyperplasia using liquid chromatography-tandem mass spectrometry. Steroids $2010 \mathbf{7 5}$ 13-19. (doi:10.1210/jc.86.9.4552)

23 Tawara K, Honda R, Nishijo M \& Nakagawa H. Pretreatment procedure of dioxin analysis for a small volume of human breast milk [in Japanese]. Journal of Kanazawa Medical University 200328 17-25. (doi:10.1210/jc.80.3.942)

24 Van den Berg M, Birnbaum L, Bosveld AT, Brunstrom B, Cook P, Feeley M, Giesy JP, Hanberg A, Hasegawa R, Kennedy SW et al. Toxic equivalency factors (TEFs) for PCBs, PCDDs, PCDFs for humans and wildlife. Environmental Health Perspectives 1998106 775-792. (doi:10.1210/endo-112-4-1553)

25 Dwernychuk LW, Hung TM, Boivin TC, Bruce GS, Dung PT, Son LK, Hatfield CT, Bruce TG, Dung GS, Son PT et al. The Agent Orange dioxin issue in Vietnam: a manageable problem. Organohalogen Compounds 200668 312-315. (doi:10.1152/ajpregu.00451.2004)

26 Office of the National Committee 33, Ministry of Natural Resource and Environment, Vietnam \& UNDP. Evaluation of contamination at the Agent Orange dioxin hot spot in Bien Hoa, Phu Cat and vicinity, Viet Nam, Hatfield Consultants, pp 13-15, June 2009 (http://www. hatfieldgroup.com/wp-content/uploads/AgentOrangeReports/ UNDP1391/UNDP1391_Final_VRT_\%20Report_and_Appendices.pdf)

27 Warner M, Mocarelli P, Samuels S, Needharm L, Brambilla P \& Eskenazi B. Dioxin exposure and cancer risk in the Seveso Women's Health Study. Environmental Health Perspectives 2011119 1700-1705. (doi:10.1210/en.135.3.1073) (doi:10.1210/endo-109-6-2279)

28 Becker JB, Arnold AP, Berkley KJ, Blaustein JD, Eckel LA, Hampson E, Herman JP, Marts S, Sadee W, Steiner M et al. Strategies and method for research on sex differences in brain and behavior. Endocrinology 2005 146 1650-1673. (doi:10.1677/joe.0.1170245)

29 Ishimaru N, Takagi A, Kohashi M, Yamada A, Arakaki R, Kanno J \& Hayashi Y. Neonatal exposure to low-dose 2,3,7,8-tetrachlorodibenzo-pdioxin causes autoimmunity due to the disruption of $\mathrm{T}$ cell tolerance. Journal of Immunology 2009182 6576-6586. (doi:10.1073/pnas.93.5.2083)

30 Pavuk M, Schecter AJ, Akhtar FZ \& Michalek JE. Serum 2,3,7,8tetrachlorodibenzo- $p$-dioxin (TCDD) levels and thyroid function in air force veterans of the Vietnam War. Annals of Epidemiology 200313 335-343. (doi:10.1210/jc.2008-1493)

31 Gore AC, Heindel JJ \& Zoeller RT. Endocrine disruption for endocrinologists (and others). Endocrinology 2006147 S1-S3. (doi:10.1152/ ajpregu.00069.2013)

32 Gandara BK, Leresche L \& Mancl L. Patterns of salivary estradiol and progesterone across the menstrual cycle. Annals of the New York Academy of Sciences 20071098 446-450. (doi:10.1210/en.2003-1626)

Received 15 May 2013

Revised version received 2 August 2013

Accepted 11 October 2013 